\title{
Effect of Diazinon on Organosomatic Indices and Behavioural Responses of Clarias gariepinus (a Common Niger Delta Wetland Fish)
}

\author{
INYANG Iniobong R. ${ }^{* 1}$, OLLOR A.0. ${ }^{2}$, and \\ IZAH Sylvester C. ${ }^{1}$
}

\author{
${ }^{1}$ Environmental Toxicity Research Unit, Department of Biological Sciences, Niger Delta \\ University, Wilberforce Island, Bayelsa State, Nigeria. \\ ${ }^{2}$ Department of Medical Laboratory Science, Rivers state University of Science and \\ Technology, Port Harcourt, Rivers State, Nigeria.
}

Article No.: 020917021

Type: Research

DOI: 10.15580/GJBS.2017.2.020917021

\section{Submitted: 14/01/2017}

Accepted: 18/01/2017

Published: 27/02/2017

\section{*Corresponding Author}

Iniobong $R$. Inyang

E-mail: dr.inyang2009@gmail.com

\section{Keywords:}

Clarias gariepinus, organosomatic

\begin{abstract}
Lethal and sublthal concentrations of toxicants affect on fish behaviour, reproduction, growth and general physiological processes in exposed organism. The purpose of this research was to determine the organosomatic indices and behavioural responses of Clarias gariepinus exposed to diazinon. Adult fish (mean length, $35.24 \pm 2.80 \mathrm{~cm}$ ) were acclimated to laboratory conditions for 7 days and then exposed to varying sublethal concentrations of diazinon $(1.00,2.50,5.00,7.50$ and $10.0 \mathrm{mg} / \mathrm{l})$ in a semistatic bioassay for 30 days. Organosomatic index was determined in the liver, spleen, kidney and heart. Fish behaviour was also monitored for several hours on and before exposure to diazinon. The final condition factor values were not statistically significant $(P>0.05)$. All organosomatic indices tested were significant, unveiling the effect of diazinon on the probe organism organs. Behavioural aberrations were also observed in experimental group/treatment that received the highest dose of the toxicant. Based on the results, diazinon used for agricultural are anthropogenic purposes could have a devastating effect on Clarias gariepinus (a common Niger Delta wet land fish).
\end{abstract}




\section{INTRODUCTION}

In spite of the immerse contribution of pesticides to agriculture and household uses, they have been reported to have negative ecological consequences on the environment (Far et al., 2012). The food chain/web is majorly affected. Pesticides applied in agricultural field or careless management of used pesticide containers find their way into the aquatic environment, either through water run-off and or as aerosols carried by wind (Inyang et al., 2016a-f, 2017).

Pesticides are classified according to their function including herbicides, insecticides, fungicides, acaricides, fumigants etc. They are also classified based on their chemical composition. Irrespective of their mode of classification, they affects target organisms, and in some cases non-target organisms as well.

Organophosphate insecticides are widely used to control a variety of agricultural pests as well as ectoparasites in fish. The organophosphorus based insecticides are derived from the phosphoric or phosphorothioic acid (Díaz-Resendiz et al., 2015). Organophosphorus pesticides are group of highly toxic compounds and they are readily available commercially for domestic, agricultural and industrial purposes (Aardema, 2008; Kapka-Skrzypczak et al., 2011). They account for about $50 \%$ of all insecticides applied worldwide (Yang and Deng, 2007). Organophosphorus insecticides are toxic because of their inhibition of the enzyme acetylcholinesterase (AlGhanim, 2014; Muranli et al., 2015). These inhibition processes of the enzyme may results in the accumulation of acetylcholine in nerve tissue and effector organs, with the main site of action being the peripheral nervous system (PNS) (National Research Council, 1982; Hodgson et al., 2004).

Diazinon (an organophosphrate insecticide) is one of the most frequently used pesticides in the world (Muranli et al., 2015). According to Al-Ghanim (2014), diazinon is the most generally used pesticide in agricultural field and environmental health. In Nigeria, it is sold in an open market and it is well embraced by farmers. Diazinon is mostly used for the control flies, lice, insect pests (of ornamental plants and food crops, nematodes and soil insects in lawns and croplands (Vajargah et al., 2013), and other insect pest such as cuttworms, wireworms and maggots in soil and ectoparasites on sheep (Virtues and Clayton, 1997). Additionally diazinon uses in urban areas include dormant sprays on fruits trees, professional landscape and pest control services (Baily et al., 20000$)$ ). Diazinon may be found in formulations with a variety of other pesticides such as pyrethroids lindane and disulpoton. The mechanism of toxic effect of diazinon is the same as those of other organophosphate substances (Leudke and Bartley, 2006).

Lethal and sublethal concentrations of toxicants usually have adverse effect on fish behaviour, haematology, histopathology, growth, reproduction, feeding and general physiological developments of exposed organisms (Butler, 1971). This research work examines the suitability of somatic indices of Clarias gariepinus as yet effective biomarkers of diazinon induced stress in fish.

\section{MATERIALS AND METHODS}

Fish samples for this study were purchased from a private fish farm at Abuloma road, Port Harcourt, Rivers State of Nigeria. The fish samples were transported to the Department of Fisheries and Aquatic environment, Rivers State University of Science and Technology, Port Harcourt, Nigeria, were the assays were conducted. Fifty-eight adult Clarias gariepinus (mean weight $275 \pm 53.12 \mathrm{~g}$, mean length, $35.24 \pm 2.80 \mathrm{~cm}$ ) were acclimatized individually in rectangular aquaria for one week during which they were fed once a day (9.00-11.00 hours) with $35 \%$ crude protein diet at $1 \%$ biomass.

Sublethal concentrations of diazinon for the assay $(1.0,2.5,5.0$, and $10.0 \mathrm{mg} / \mathrm{l})$ were determined based on the range finding test (Inyang, 2008). These were prepared by transferring $0.02,0.013,0.25,0.37$ and $0.5 \mathrm{ml}$, respectively of the original concentration of diazinon and making it up to $30 \mathrm{~L}$ with borehole water in the aquaria, $30 \mathrm{~L}$ of the diluent water was used as control. Four replications of each treatment level (concentrated) and control were set up by introducing fishes individually into each aquarium. Daily renewal bioassay was employed during the experiment which lasted for 30 days. The physico-chemical properties of the water used for the fish bioassay was carried out using standard methods (APHA, 1998); The result of the water quality were; temperature $26^{\circ} \mathrm{C}, \mathrm{pH} 6.620-$ 6.37, dissolved oxygen $5.38-7.21 \mathrm{mg} / \mathrm{l}$, alkalinity $15.25-17.09 \mathrm{mg} / \mathrm{l}$, conductivity $99.50-136.12 \mu \mathrm{s} / \mathrm{cm}$ and turbidity $0.042-0.50$ NTU.

After 30 days of exposure, fishes were weighed before sacrifice for collection of target organs (heart, liver, kidney, and spleen) for organosomatic index text (OIT). The OIT was determined by weighing each organ on digital weighing balance. Organosomatic index for all the organs was calculated using the expression:

\section{$\frac{\text { prgan weight (g) }}{\text { rotal body weight }} \times 100$ (Simeon, 2007)}

While the condition factor $(k)$ of each specimen was calculated using foulton's formular:

$$
\mathrm{K}=\frac{100 \mathrm{~W}}{2 z} \times 100
$$

$\mathrm{W}=$ weight of fish

$L=$ Length of fish

Fishes were closely observed for abnormal or adverse behavioural change outside the normal range of variability, during and after exposure to diazinon. 


\section{Data analysis}

The data were subjected to analysis of variance (ANOVA). Where variation exist, Duncan multiple range test (DMRT) were used determine the source of the observed difference between treatments at $\mathrm{P}=0.05$ (Wahua, 1999).

\section{RESULTS AND DISCUSSION}

\section{Condition factor}

The initial condition factor of the control and experimental group values were not statistically significant $(P>.05)$. Albeit a slight progressive rise in values were observed as the concentration increased. The final condition values were not significantly different $(\mathrm{P}>0.05)$. Values fluctuate as the concentration increased. A slight increase in values at
$1.00 \mathrm{mg} / \mathrm{l}$ and $2.50 \mathrm{mg} / \mathrm{l}$ were recorded and then a reduction in values at $5.00,7.50$ and $10.0 \mathrm{mg} / \mathrm{l}$ (Table 1). A sudden drop in values is clear indication of effect of diazinon on general physiology of the probe organism.

\section{Organosomatic index}

Our data unveiled a statistically significant values in all somatic indices tested. A slight deviation in values was recorded in the cardiosomatic (Heart) and Spleenosomatic indices. Renosomatic (kidney) and spleenosomatic (Spleen) indices values reduced as the concentration of the toxicant increases. These fluctuation in values showed the effect of diazinon on these organs. The results were similar to those of Clarias gariepinus exposed to monoclotophos insecticide (an organophosphorus insecticide) for 30 days (Simeon, 2007).

Table 1: Condition factor of Clarias gariepinus exposed to diazinon for 30 days (mean \pm SD)

\begin{tabular}{|c|c|c|c|c|}
\hline $\begin{array}{c}\text { Conc of } \\
\text { diazinon }(\mathrm{mg} / \mathrm{l}\end{array}$ & $\begin{array}{l}\text { Initial Condition } \\
\text { (K1) }\end{array}$ & $\begin{array}{c}\% \text { of } \\
\text { Control }\end{array}$ & $\begin{array}{l}\text { Final Condition } \\
\text { (K2) }\end{array}$ & $\begin{array}{c}\text { \% of } \\
\text { Control }\end{array}$ \\
\hline 0.00 & $0.68 \pm 0.14^{\mathrm{a}}$ & 100 & $0.69 \pm 0.12^{\mathrm{a}}$ & 100 \\
\hline 1.00 & $0.88 \pm 0.14^{a}$ & 129 & $0.78 \pm 0.15^{a}$ & 113 \\
\hline 2.50 & $0.72 \pm 0.15^{a}$ & 106 & $0.72 \pm 0.15^{a}$ & 104 \\
\hline 5.00 & $0.76 \pm 0.12^{\mathrm{a}}$ & 112 & $0.68 \pm 0.69^{a}$ & 99 \\
\hline 7.50 & $0.67 \pm 0.08^{a}$ & 99 & $0.59 \pm 0.06^{a}$ & 86 \\
\hline 10.0 & $0.70 \pm 0.07^{a}$ & 103 & $0.63 \pm 0.07^{a}$ & 91 \\
\hline
\end{tabular}

Means with the same superscript in the row are not significantly different $(p<0.05)$.

Table 2: Condition factor of Clarias gariepinus exposed to diazinon for 30 days (mean \pm SD)

\begin{tabular}{|c|c|c|c|c|}
\hline $\begin{array}{l}\text { Conc of } \\
\text { diazinon }(\mathrm{mg} / \mathrm{l}\end{array}$ & $\begin{array}{l}\text { Renasomatic } \\
\text { (kidney) }\end{array}$ & $\begin{array}{c}\text { Cardiosomatic } \\
\text { (Heart }\end{array}$ & $\begin{array}{l}\text { Hepetosomatic } \\
\text { (Liver }\end{array}$ & $\begin{array}{c}\text { Spleenosomatic } \\
\text { (Spleen) }\end{array}$ \\
\hline 0.00 & $0.01 \pm 0.02^{b}$ & $0.18 \pm 0.03^{a}$ & $1.29 \pm 0.32^{\mathrm{ab}}$ & $0.23 \pm 0.03^{b}$ \\
\hline 1.00 & $0.8 \pm 0.03^{a}$ & $0.15 \pm 0.02^{\mathrm{ab}}$ & $1.28 \pm 0.45^{\mathrm{ab}}$ & $0.9 \pm 0.03^{b}$ \\
\hline 2.50 & $0.09 \pm 0.02^{\mathrm{a}}$ & $0.14 \pm 0.02^{a b}$ & $1.27 \pm 0.35^{\mathrm{ab}}$ & $0.11 \pm 0.04^{b}$ \\
\hline 5.00 & $0.08 \pm 0.02^{a}$ & $0.13 \pm 0.03^{a b}$ & $1.25 \pm 0.39^{a b}$ & $0.07 \pm 0.01^{b}$ \\
\hline 7.50 & $0.10 \pm 0.01^{a}$ & $0.16 \pm 0.03^{a}$ & $1.45 \pm 0.35^{a}$ & $0.08 \pm 0.04^{b}$ \\
\hline 10.0 & $0.09 \pm 0.01^{a}$ & $0.14 \pm 0.05^{\mathrm{ab}}$ & $1.44 \pm 0.23^{a}$ & $0.07 \pm 0.03^{b}$ \\
\hline
\end{tabular}

Means with the same superscript in the row are not significantly different $(p<0.05)$. 
Pesticides are metabolized in the liver through cytochrome P450 to hepatotoxic intermediates (Das and Gupta, 2013). Several field and laboratory studies have recorded an increase in hepatosomatic indices in fishes exposed to pesticides (Krurutap and Duran, 2001; Roche et al., 2000. Liver values increased slightly at the last two concentrations of diazinon (7.50 and $10.00 \mathrm{mg} / \mathrm{l})$. Liver enlargement suggests increased detoxification processes.

Spleen filters foreign substances from blood cells, release blood to sections in need, while kidney plays the major role in excretion of nitrogenous waste, control of water and electrolyte balance in the fish. A significant decline in size of these organs as recorded in this present study could impair these functions resulting in a more toxic internal environment which is detrimental to the fish.

\section{Behavioural observation}

There was no behavioural changes in the control and the first group that received the least dose $(1.00 \mathrm{mg} / \mathrm{l})$ of the toxicant. The rest of the doses caused changes in behavioural patterns. Slight restlessness was observed in the group/treatment that received the highest dose of the toxicant. Intermediately the fish turned on the flank and swam in half circles and weakening of jerks were observed. Also, sudden quick movement, settling at the bottom and excessive mucus secretion on the skin were observed. Additionally, fishes showed unusual movement as a result muscle spasm and lethargy. Similarly findings have been reported by several researchers in a number of fish species including Clarias gariepinus, Heterobrancus bidorsalis, Common Carp (Cyprinus carpio L) and Branchydario rerio (Omeregie and Okpanachi 1992; Svobodova et al., 2001; Avoajeh and Oti, 2002; Auta et al., 2004). These abnormal behavioural responses exhibited by Clarias gariepinus in this present study suggest that they suffered respiratory impairment due to the effect of the toxicant precisely on gills and general metabolism.

\section{CONCLUSION}

Our data and physical observation unveiled the effect of diazinon on Claria gariepinus. We also observed that the concentration of diazinon that caused negative effect (specially, the behavioural responses) was much lower than anticipated, hence anywhere this insecticide run-off is present; it is assumed that organism in that microenvironment will suffer negative effects from exposure to diazinon. Further research of the impact of diazinon on developing aquatic organisms should be done for better understanding of the effect of diazinon in aquatic ecosystem.

\section{REFERENCES}

Aardema, H., Meertens, J., Ligtenberg, J., PeterPolman, J.E, Tulleken J.E. and ljistra, G. 2008. Organophosphorus pesticide poisoning: cases and developments, Neth. J. Med., 66: 149 - 153.

Al-Ghanim, K.A. 2014. Effect of an Organophosphate Insecticide Diazinon on the Activity of Acetylcholinesterase and Lipid Peroxidation of a Common Carp, Cyprinus Carpio L. Pakistan J. Zool., 46(1): 161-166.

APHA (American Public Health Association) 1988. Standard methods for examination of water and waste water. APHA, Washington D.C.

Auta, J., Balogun, J.K., Lawal, F.A. and Ipinjolu, J.K. 2004. Acute toxicity of the insecticide, Dimethoate on juveniles of Oreochromis niloticus (Trewavas) and Clarias gariepinus (Teugels). J. Aquatic Sciences, 19 (1): 5-8.

Avoajah, D.A and Oti, E.E. 1997. Effects of sublethal concentration of some pesticides on the growth and survival of the fingerlings of the African Catfish. Nigeria Journal of Biotechnology, 8:4045.

Baily, H.C., Deanovic, L., Reyes, T., Kimball, K., Larson, K., Connar, V. and Hinton, D.E. 2000. Diazinon and Chlorophyrifos in urban water ways in Northern California. Env. Toxicol. Chem. 19:82 $-87$.

Butler, P.A. 1971. Influence of pesticides on marine ecosystem.

Das, S. and Gupta, Abhik. 2013. A study on acute toxicity, behaviour and growth in Indian flying barb, Esonus Dauricus (Hamilton - Buchanan) on exposure to organchlorine pesticide Endosulfan (EC35). Inter. J. Env. Sci. 3.2217-2223.

Díaz-Resendiz, K. J. G., Toledo-lbarra, G. A. and Girón-Pérez, M. I. 2015. Modulation of Immune Response by Organophosphorus Pesticides: Fishes as a Potential Model in Immunotoxicology. Journal of Immunology Research, http://dx.doi.org/10.1155/2015/213836

Far, M.S., Roodsari, H.V., Zamini, A., Mirrasooli, E. and Kazemi, R. (2012). Effects of Diazinon on Behavior and Some Hematological Parameters of Fry Rainbow Trout (Oncorhynchus mykiss). World Journal of Fish and Marine Sciences 4 (4): 369-375.

Hodgson, E., Leidy, R., and Cope, V.2004. A textbook of modern toxicology. John Wiley and sons Pub: Hoboken New Jersey.

Inyang I.R, Thomas S and Izah, S.C. 2016a. Evaluation of activities of transfereases and phosphate in plasma and organs of Clarias gariepinus exposed to fluazifop-P-butyl. Journal of Environmental treatment techniques 4(3): $94-$ 97

Inyang, I.R., Kenobi, A. and Izah, S.C. 2016b. Effect of dimethoate on some selected metabolites in the brain, liver and muscle of Clarias lazera. Sky Journal of Biochemistry Research. 5(4): 63-68

Inyang, I.R., Akio, K. and Izah, S.C. 2016c. Effect of dimethoate on lactate dehydrogenase, creatinine 
kinase and amylase in Clarias lazera. Biotechnological Research, 2(4): 155- 160

Inyang, I.R., Obidiozo, OZ. and Izah, S.C. 2016d. Effects of Lambda cyhalothrin in protein and Albumin content in the kidney and liver of Parpohiocephalus obscurus. EC Pharmacology and Toxicology, 2(3): 148-153

Inyang, I.R., Okon, N.C. and Izah, S.C. 2016e. Effect of glyphosate on some enzymes and electrolytes in Heterobranchus bidosalis (a common African catfish). Biotechnological Research, 2(4):161-165

Inyang, I.R., Thomas, S. and Izah, S.C. $2016 \mathrm{f}$

Activities of electrolytes in kidney and liver of Clarias gariepinus exposed to fluazifop-p-butyl. Journal of Biotechnology Research, 2(9): 68 - 72. Inyang, I.R., Izah, S.C., Johnson, D.T. and Ejomarie, O.A. 2017. Effects of Lambda cyhalothrin on some electrolytes and metabolites in organs of Parpohiocephalus obscurus. Biotechnological Research, 3(1): 6-10.

Inyang, I.R. 2008. Haematological and biochemical responses of Clarias gariepinus to diazinon phD thesis, Rivers State University of Science and Technology, Port Harcourt. $138-153$.

Kapka-Skrzypczak, L., Cyrank, M., Skrzypczak, M. and Kruszewski, M. (2011). Biomonitoring and biomarkers of organophosphate pesticides exposure -state of the art. Annals of Agricultural and Environmental Medicine, 18(2): 294-303

Kuruptap E.B., and Daoran F., 2001. The effects of endosulfan on activity and kinetic properties of Lactic dehydrogerase enzyme: A biochemical and Histopathological study, T. Klin. J. Med. Sci., 21:11-16

Leudke, K and Bartley, M. 2006. Phisiological effects of diazinin of fat head minnows fry (Pimephales promelas) Archieves of Environmental Contamination and Toxicology, 2: 70-76.

Muranli, F.D.G., Kanev, M. and Ozdemir, K. (2015). Genotoxic effects of diazinon on human peripheral blood lymphocytes. Arh Hig Rada Toksikol 2015;66:153-158
National Research Council (1982). Possible LongTerm Health Effects of Short-Term Exposure to Chemical Agents: Volume 1 Anticholinesterases and Anticholinergics.

https://www.ncbi.nlm.nih.gov/books/NBK217772/. Accessed February 08th , 2017

Omeregie, E and Okpanachi, M.A. 1992. Growth of tilapia zilli exposures to sublethal concentration of crude extracts of Azadirachta indica. Acta Hydrobiologica, 34(2): 281-286.

Roche H., Bult, A., Jonet, O., and Ramade, F. 2000. Organochlorine residues in European ed (Anguilla Anguilla), crucian carp (Carassius carassius) and catfish (Ictalurus nebulosus) from vaccares lagoon (French National Nature reserve of Camargue - effect of some physiological parameters. Aquatic Toxicology, 48:443-459

Simeon, E.O 2007. Effect of monoclotophos (an organophosphate insecticide)on organosomatic indices and enzymes activity of a hybrid catfish. Msc thesis, Rivers State University of Sc and Tech. Port Harcourt.

Svodovora, M., Luskova, V., Drastichora, J. and Zlabek, 2001. Effect if diazinon on haematological indices of common carp (Cyprinus carpio). Acta Vet. Brno. 70:457-465.

Vajargah, M.F., Hossaini, S.A. and Hedayati, A. (2013). Acute toxicity test of two pesticides diazinon and deltamethrin on spirlin (Alburnoides bipunctatus) larvae and fingerling. Journal of Toxicology and Environmental Health Sciences, 5(6): 106-110

Virture, W.A and Voetorra, J.W. 1997. Sheep dip chemicals and water pollution. Environmental Toxicology, 22:194-196.

Wahua, T.A.T. 1999. Applied statistics for scientific studies, Africa link books, Ibadan.

Yang, C. and Deng, J. 2007. Intermediate syndrome following organophosphate poisoning. J. Chin.

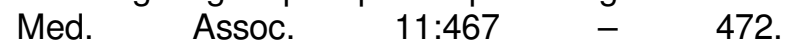

